\title{
DETERMINATION OF THE PASTING PROPERTIES OF HORSE-EYE BEAN FLOUR (Mucuna Sloanei) VARIETIES RELEVANT TO ITS PROCESSING
}

\author{
${ }^{1}$ Ide, P. E.; ${ }^{2}$ Oluka, S.I. and ${ }^{3}$ Eze, P.C. \\ ${ }^{1,2,3}$ Agricultural and Bio-resource Engineering, Enugu State University of Science and \\ Technology, Enugu, Nigeria.
}

Corresponding authors email. patrick.ejike@esut.edu.ng

\begin{abstract}
Horse-Eye Bean seeds are edible rich source of several essential nutrients which can be processed into flour for several purposes. The aim of this study was to evaluate the pasting properties of flour processed from species of Horse-Eye Bean seed using Rapid Visco-analytical machine. The results obtained showed that peak viscosity, trough viscosity, breakdown viscosity, final viscosity, setback viscosity were 294.84 RVU, 219.50RVU, 75.34 RVU, 838.96 RVU, and 619.46 RVU for the Big-Sized sample flour and 271.30 RVU, 207.92 RVU,67.37RVU, 723.46 $R V U$, and $576.83 R V U$ for the Small-Sized sample flour respectively. It showed that Horse-Eye Bean flours can be used to improve food quality and their suitability for various food formulations. Hence they can find useful application for making of pastries like cakes and other snacks.
\end{abstract}

Keywords: Horse-Eye Bean flour, Pasting properties, Rapi Visco Analyzer, viscosity. https://dx.doi.org/10.4314/jafs.v17i2.2

\section{INTRODUCTION}

In the recent days, interest has been given to lesser known and underutilized crop with high potential values for alternative for human and animal food and new food products development. Horse-Eye bean is among the over hundred species of shrubs and climbing vines that is generally accepted due to its important benefits to humans and their environment (Obiakor-Okeke, 2014). Horse-Eye bean is a climbing shrub with twining stem that can be $6-8$ meters long. The young fruit is cooked and eaten as vegetable while the ripped seed is cooked and pounded, eaten preferably with soup, (Nwosu, 2012). In Nigeria, Horse-Eye bean is known to have different native names with regards to their tribe and ethnic group. In Igbo, it is known as ' $U K P O$ ', or 'OKOBO', and also known as 'KARASUU', in Hausa, and 'YEREPE', in Yoruba, and "IBABAT'" in Efik, (Obochi et al., 2007). It is used in the making of food condiments in the South Eastern part of Nigeria. The seed can be roasted, fermented and parboiled for easy removal of the hull and then grinded to obtain a fine powder or paste when wet or dried milled. The paste is used as a recipe of some food items, for baking and in beverages, (Wanjekeche et al., 2003). Horse-Eye bean positive health properties are nutritional composition, Journal of the Faculty of Agriculture and Veterinary Medicine, Imo State University Owerri website: www ajol.info 
pharmaceutical/medical properties and functional properties while its negative properties are toxic at any concentration, toxic after critical concentration level and excessive or unbalanced intake (Natarajan and Ravichandra., 2012). The importance of Horse-Eye bean is based on its high content of lysine and protein, these are usually limited in sulphur-containing amino acid particularly methionic (Nwosu, 2011). It contains phosphorus, but very little in the supply of iron and calcium, (Okaka, 2006).

Rheology is described as the discipline which investigates the agricultural product deformation and flow (Ehimen and Abiodun, 2017). Information from rheological analysis is needed in agricultural material evaluation quality, computation of engineering data, and process design. The knowledge on deformation-flow characteristics and behavior are very necessary to decide or establish actual ranges of the pump and pipe sizes and energy needed during processing of food. Models obtained from the rheological calculations from the measured experiments could be highly effective in the design of food process when applied concurrently through energy, force, and load proportions. Therefore, it is of very important that the various agricultural products and food materials are examined to verify their natural benefits which will in turn improve the good quality of life and existence of man (Gipsy and Gustavo, 2005). There are limited literature on the pasting characteristics of varieties of Horse-Eye bean flour. Hence, this research is aimed at determining and comparing the pasting properties of two varieties of Horse-Eye bean flour in order to explore its numerous potentials in the food system and increase their uses and also reduces post-harvest losses.

\section{MATERIALS AND METHOD}

\section{Source of Sample and Preparation}

The Horse-Eye bean samples used for this research work were harvested from a local farm in Enugu State, Nigeria. The seed varieties of Horse-Eye bean were properly cleaned and sorted to select viable seeds. The sample was parboiled for 60 minutes. The boiled seeds were manually dehulled, oven dried for 120 minutes at $60{ }^{\circ} \mathrm{C}$, milled into flour using disc attrition mill and sieved with American Standard Sieve with $435 \mathrm{ppm}$ aperture to obtain fine flour. The processed flour was packaged in airtight containers with proper labelling and then moved to the laboratory were pasting properties were analysed using Rapid Visco-Analyzer of model RVA 4500 Newport Scientific Australia.

\section{Determination of the Pasting Properties of Horse-Eye Bean Flour}

The Pasting properties of the Horse-Eye bean flour samples were determined using a Rapid Visco Analytical machine (RVA) of model RVA 4500, New-Port Scientific, Australia as described by Iwe et al., (2016). The starch is gelatinized with steadily rise in viscosity and subjected to high temperature and controlled shear when its stability is revealed, then cooled to provide an indication of setback during gelation. $3.0 \mathrm{~g}$ of the sample was weighed into a 
previously dried canister and $25 \mathrm{ml}$ of distilled water was dispensed into the canister containing the sample. The suspension was thoroughly mixed and the canister was fitted into the Rapid Visco Analyser as recommended. Each suspension was kept at $50{ }^{\circ} \mathrm{C}$ for $1 \mathrm{~min}$ and then heated up to $95{ }^{\circ} \mathrm{C}$ with a holding time of 2 minutes followed by cooling to $50{ }^{\circ} \mathrm{C}$ with 2 minutes holding time. The rate of heating and cooling were at a constant rate of $11.85{ }^{\circ} \mathrm{C}$ per min. Samples were assessed for pasting temperature, peak paste viscosity time to peak temperature at peak, hot and cold paste viscosity break down setback and final viscosity.

\section{RESULTS AND DISCUSSION}

The pasting characteristics of the flours obtained from the different Horse-Eye bean flour samples were shown in Table 1 and Figure 1. The pasting properties of the flour samples were significantly different at $(\mathrm{p}<0.05)$. The Big-Sized flour sample of the Horse-Eye bean started pasting at $87.89{ }^{\circ} \mathrm{C}$ and reached at peak viscosity of $294.38 \mathrm{RVU}$ in 5.82 minutes. While the Small-Sized Horse-Eye bean started pasting at $97.39{ }^{\circ} \mathrm{C}$ and reached at peak viscosity of 270.75 at 5.08 minutes. The pasting temperature for the both flour samples slightly varied and both ranging from $87.89^{\circ} \mathrm{C}$ and $97.39^{\circ} \mathrm{C}$ for Big and Small-Sized Horse-Eye bean respectively.

The peak viscosity of the flour samples was 294.38 and 270.68 RVU for both Big and SmallSized Horse-Eye bean flour respectively. Peak Viscosity which is the maximum viscosity obtainable during the heating processes and it also measures the index of water binding capacity of the flour and gives an insight on the high swelling ability as a results of more rigid polymers structure of granules. From the Table 1, it was also observed that the Big-Sized Horse-Eye bean flour exhibited a higher Peak Viscosity of 294.38 RVU, than the Small-Sized sample flour (270.75 RVU). This indication shows that the Big-Sized Horse-Eye bean sample flour is most suitable for development of new food products where high gelling strength and elasticity is required. The lower the peak viscosity of the sample, the more the products tends to swells and the higher the peak viscosity, the more the product gells. Therefore, the lowest peak viscosity displayed by the Small-Sized Horse-Eye bean flour sample of 270.75 RVU, indicates that it swells more than Big-sized Horse-Eye bean. This is highly recommended when the swelling capacity is needed.

Trough viscosity measures the ability of the paste or gel formed to withstand breakdown during cooling, (Ehimen et al., 2017). The trough viscosity is an index of starch granule stability to heating and it is the minimum viscosity in the constant temperature phase of the RVA profile. Trough viscosity recorded from Table 1, are 219.54 RVU and 207.95 RVU for Big and SmallSized Horse-Eye bean flour sample respectively. This higher value recorded by the Big-Sized Horse-Eye bean indicates that the higher the trough, the higher the holding strength property of the sample and its ability of the granules to withstand distortion when the flour is subjected to shear stress and heating. 
The final viscosity is used to define the particular quality of starch and this indicates the stability of the cooked paste in actual use, it also indicates the ability of the starch to form viscous paste or gel after cooling and less stability of starch paste commonly accompanied with high value for breakdown, (Uzomah et al., 2011). The final viscosity (cool-paste viscosity) recorded highest value at Big-Sized Horse-Eye bean as 838.60 RVU which indicates high retrogression and precipitation of linear molecules and this retrogradation tendency was as a result of the present of hydrocolloids and amylose content in the flour sample, (Uzomah et al., 2011). The total setback viscosity (SB) is the difference between final viscosity (FV) and trough viscosity (TV) and it is an indication of how starch molecules behave after heating, cooking and cooling, an index of retrogradation of the linear starch molecules during cooling. The flour processed from the BigSized Horse-Eye Bean flour sample showed the highest retrogradation of 619.30 RVU during cooling while the Small-Sized Horse-Eye bean flour sample which showed lowest setback of 576.15 RVU, indicates a good potential for use in frozen foods. The breakdown which is a measure of disintegration of the particle structures of the starch granules at the constant heating temperature illustrating the paste stability during cooking, was also recorded in Table 1. It was observed that the Big-Sized Horse-Eye bean flour recorded the highest breakdown of 75.50 RVU, while the lowest breakdown viscosity was recorded by Small-Sized Horse-Eye bean as 67.42 RVU, indicating very poor capacity of the paste to withstand severe processing. Low breakdown viscosity may also suggest that the starch possesses cross-linking properties (Uzomah et al., 2011).

\section{CONCLUSION}

The results of the pasting properties showed that the observed differences were statistically significant with respect to species and thus shows that species greatly influenced pasting properties at 0.05 level of significance and $95 \%$ confidence interval. The f-values were 2.93 and 189.69 and were lower and higher than f-critical 5.98 and 4.28 respectively. In this research, pasting properties of Horse-Eye bean flour varied with respect to specie and the highest pasting properties of the sample flour values were obtained from the Big-Sized Horse-Eye bean species. Horse-Eye Bean flours showed that it can be used to improved food quality and their suitability for various food formulations. Hence they can find useful application for making of pastries like cakes and other snacks. 


\section{REFERENCES}

Adebowale, B. C and Lawal C. (1986) Food Gums and Ingredients $2^{\text {nd }}$ Edition, Academic Press. Adebowale BC, Lawal C (1986). Academic press, 21:34 - 45.

Ajayi et al., (2006). Oil Content and Fatty Acid Composition of Some Underutilized Legumes from Nigeria. Food Chemistry, 991: 115-120

Akpata A.O and Miachi E.U (2001) Chemical Composition and Selected Functional Properties of Sweet Orange and Legumes. Flours Plant Foods Humam Nutritions. 54:353-362.

Akpata M. I and Muachi O. E. (2001). Proximate Composition and Selected Functional Properties of Deuterium Microcarpum. Plant food Hum. Nutri., 56:pg (297-302).

Ehimen R. Ohizua and Abiodun A. (2017).On nutrient composition, functional and Pasting properties of Unripe cooking banana,pigeon pea and sweet potato flour blends .5(3): pg (750-762). Food Sci Nutr. 12;5(3):750-762. doi: 10.1002/fsn3.455

Gipsy Tabilo-Munizaga and Gustavo V. Barbosa-Canovas (2005). Rheology for the food industry. Journal of Food Engineering 67:147-156. www.elsevier.com/locate/jfoodeng

Iwe, M.O, Onyeukwu, U., and Agiriga, A.N. (2016). Proximate, functional and pasting properties of FARO 44 rice, African yam bean and brown cowpea seeds composite flour. Cogent Food \& Agriculture, 2; ID: 1142409.

Natarajan K, Narayanam N and Ravichandra N. A (2012). Review on 'Mucuna' - The Wonder Plant. Int. J Pharm. Sci. Rev., 17 (1)18:86-93.

Nwosu, J.N, C. C, Owuamanam C.I and Onvegbu N. (2012): The Effect of Storage Condition On The Proximate and Rheological Properties Of Soup Thickeners (Bruchystegia Eurycoma). Achi Report and Opinion 3(5):52-58.

Nwosu, Justina (2011). The Effect of Storage Condition on the Rheological/Functional Properties of Soup Thickener "Ukpo" (Mucuna Sloanei). Researcher 3(6):27-32.

Obiakor Okeke. P.N. and Anozie.T. (2014). Effect of Different Processing Method on the Chemical, Functional and Microbial Properties of Mucuna Sloanei Seeds (Ukpo) American Journal of Food Science and Nutrition Research 1 (14): 23 - 32.

Obochi G.O., Malu SP., Effiom E. O, Bassey G.A. (2007). Efficacy and suitability of lectin from Mucuna Sloanci Seeds Extract as a cell receptor signal inducer. Res. J. Biol Science, 2 (6): 667-669.

Okaka, J.C., Enoch, NTA. and Okaka, NCA., (2006). Food and Human Nutrition. O.J. C Academic Publishers, Enugu, Nigeria. Pp 135-153. 
Uzomah and Odusanya (2011) Mucuna sloanei, Detarium microcarpum and Brachystegia eurycoma seeds: A preliminary study of their starch-hydrocolloids system, 5(13):733740. https://doi.org/10.5897/AJFS11.088

Wanjekeche, E., Wakasa, V., Mureithi, J.G. (2003). Effect of germination alkaline and acid soaking and boiling on the nutritional value of mature and immature mucuna (mucuna pruriens) beans . Tropical and Subtropical Agroecosystems, 1 (2003): 183 - 192. 
Volume 17 Number 2, October 2019 pp 14 - 20.

APPENDIXES

Table 1: Rheological/Pasting Properties of Big and Small-Sized Horse-Eye Bean Flour.

\begin{tabular}{cccccccc}
\hline $\begin{array}{c}\text { Sample } \\
\text { Varieties }\end{array}$ & $\begin{array}{c}\text { Peak } \\
\text { viscosity }\end{array}$ & $\begin{array}{c}\text { Trough } \\
\text { Viscosity }\end{array}$ & $\begin{array}{c}\text { Breakdown } \\
\text { Viscosity }\end{array}$ & $\begin{array}{c}\text { Final } \\
\text { viscosity }\end{array}$ & $\begin{array}{c}\text { Setback } \\
\text { viscosity }\end{array}$ & $\begin{array}{c}\text { Peaktime } \\
\text { viscosity }\end{array}$ & $\begin{array}{c}\text { Pasting } \\
\text { Temp }\end{array}$ \\
\hline \multirow{2}{*}{ Big-Sized } & $\begin{array}{c}294.38 \\
(0.62)\end{array}$ & 219.54 & 75.50 & 838.60 & 619.3 & 5.82 & 87.89 \\
& $(0.55)$ & $(0.92)$ & $(1.58)$ & $(1.24)$ & $(0.05)$ & $(0.48)$ \\
Small- & 270.75 & 207.95 & 67.42 & 724.44 & 576.15 & 5.08 & 97.39 \\
Sized & $(0.68)$ & $(0.21)$ & $(0.02)$ & $(0.99)$ & $(1.02)$ & $(0.02)$ & $(0.45)$ \\
\hline
\end{tabular}

Values on the tables are the mean of three replications while Values in parenthesis are standard deviation of three replications of the pasting properties evaluated. The mean and standard deviation were determined using SPSS windos10 software.

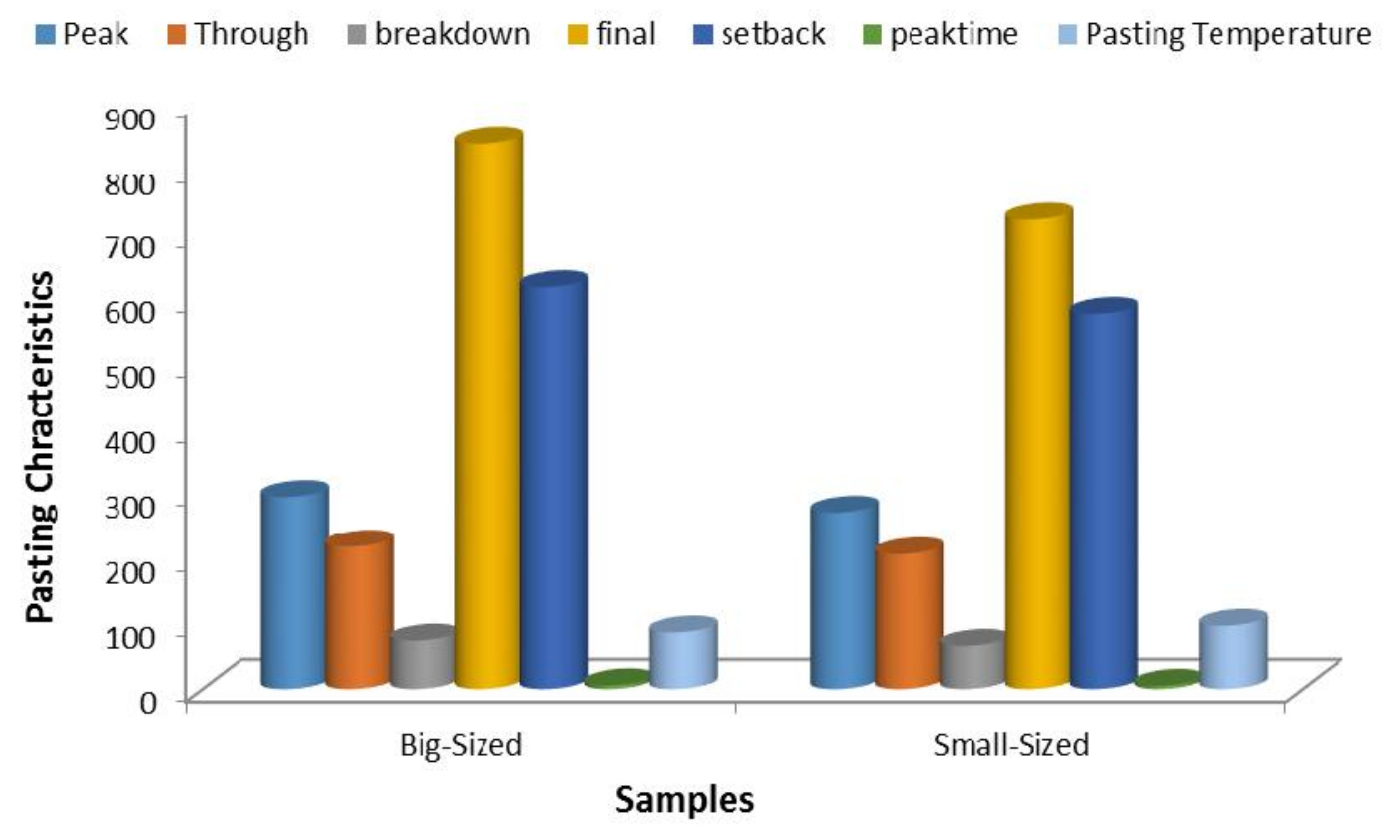

Figure 1: Graph showing Pasting Characteristics of Horse-Eye Bean Flour 